\title{
Frequency of Ponticulus Posticus in Lateral Cephalometric Radiography of Peruvian Patients
}

\author{
Frecuencia de Ponticulus Posticus en Radiografías Cefalométricas Laterales de Peruanos
}

\author{
Iván E. Pérez*; Allison K. Chávez** \& Darío Ponce***
}

\begin{abstract}
PÉREZ, I. E.; CHÁVEZ, A. K. \& PONCE, D. Frequency of ponticulus posticus in lateral cephalometric radiography of Peruvian patients. Int. J. Morphol., 32(1):54-60, 2014.

SUMMARY: The Ponticulus posticus is an anomalous ossification of unknown origin that arches backward from the superior articular process to the posterior arch of the Atlas vertebra, it can be complete or partial and houses vascular and nervous elements; it is diagnosed by lateral cervical radiography, cephalometric radiography or CT scans. The purpose for the present study was to determine the frequency of partial and complete Ponticulus posticus in lateral cephalometric radiography of Peruvian patients and identify any possible genre or age group associations. The study consisted in reviewing 1056 lateral cephalometric radiography of patients between 3-56 years old in search of partial or complete Ponticulus posticus. The mean age of subjects studied was $14.05 \pm 7.43$ years old. The Ponticulus posticus frequency was $19.79 \%$, the partial Ponticulus posticus frequency was $11.08 \%$ and the complete Ponticulus posticus frequency was $8.71 \%$; Cramer's V and ETA statistics found not significant association between the PP and the genre or the age groups ( $p>0.05$ ). The Ponticulus posticus is not an infrequent radiographic finding, our results are similar to those reported in the Americas and similar to different for other ethnic groups, we confirm that the Ponticulus posticus is not associated with genre or age and we reviewed the importance of the Ponticulus posticus in the prognosis of the Atlas-Axis surgical stabilization.
\end{abstract}

KEY WORDS: Cervical Vertebrae/radiography; Heterotopic Ossification/radiography; Cervical Atlas/abnormalities; Cervical Atlas/radiography; Atlanto-Axial Joint/radiography.

\section{INTRODUCTION}

The vertebrae of the cervical part of the vertebral column demonstrate the greatest variability and these are the smallest and the most delicate among the true vertebrae. The first cervical vertebra, the Atlas, differs in structure from all the other cervical vertebrae because it is devoid of body and spine (Sylvia et al., 2011) and it is, also, the most variable human vertebra (Wysocki et al., 2003).

The upper part of the vertebral artery (VA) groove is bridged by the oblique ligament of the Atlas (Sylvia et al.) and sometimes this ligament becomes partially or completely calcified, by an anomalous ossification (Sylvia et al.; Hasan et al., 2001; Cho, 2009; Senoglu et al., 2006; Young et al., 2005), in the form of a bony arch (Sharma et al.) that extends from the lateral mass to the posteromedial margin of the VA groove (Paraskevas et al., 2005) and delineates a foramen for the passage of vascular and nervous elements (Tubbs et al., 2007).
This bony arch/bridge has been termed differently in the literature: Ponticulus posticus (Hasan et al.; Tubbs et al.; Senoglu et al.; Young et al.; Miki et al., 1979; Krishnamurthy et al., 2007; Schilling et al., 2010; Koutsouraki et al., 2010), Ponticulus posterior of the atlas, Pons posticus, Atlas bridging, Kimmerle anomaly/variant/deformity of the atlas (Crowe, 1986), Posterior glenoid process, Posticus ponticularis (Crowe), Spiculum and Ponticulus Atlantis Posterior (Prescher et al., 1996); however, it most accepted name is Ponticulus posticus (Latin of little posterior bridge).

The foramen below the ponticulus posticus (PP) has been termed differently too: Arcuate foramen, Foramen arcuale (Wysocki et al.; Crowe), Foramen sagittale (Crowe), Foramen atlantoideum posterior, Foramen retroarticulare superior or Upper retroarticular foramen, Canalis arteriae vertebralis (Crowe), Retroarticular vertebral artery ring, Retroarticular canal and Retrocondilar vertebral artery ring,

* Radiología Oral, Centro para la Investigación de las Disarmonías Dentofaciales (CIDDENT), Lima Perú.

** Universidad Peruana Cayetano Heredia. Facultad de Estomatología. Departamento de Clínica Estomatológica, Lima Perú.

**** Estadística, Centro para la investigación de las Disarmonías Dentofaciales (CIDDENT), Lima Perú. 
Retroarticular vertebral artery ring of Atlas, Foramen atlantoideum posterius/vertebrale (Crowe), Posterior atlantoid foramen, Retrocondylar bony foramen (Wysocki et al.; Hasan et al.; Tubbs et al.; Senoglu et al.; Krishnamurthy et al.; Schilling et al.; Koutsouraki et al.; Unur et al., 2004), Perpendicular foramen (Wysocki et al.), Transverse foramen (Wysocki et al.) and Foramen atlantoideum (Crowe).

The ponticulus posticus (PP) manifests as a partial or complete bony arch/bridge in the Atlas vertebra, between the lateral mass and the posterior arch on plain film radiography of the craniovertebral junction in the lateral projection, including the cephalometric lateral radiography (Sharma et al.); but their radiological diagnosis is sometimes difficult because the limitations inherent of plain film radiography (Cho) or when the atlanto-occipital space and the posterior arch of the atlas (Miki et al.; Sharma et al.; Cho) are obscured by other structures in the vicinity, particularly the mastoid bone (Wight et al., 1999).

Determining the location and the affected side of the $\mathrm{PP}$ it is difficult with lateral and anteroposterior radiographic views (Schilling et al.); and their exact characterization is possible only by three dimensional (3D) CT reconstruction (Cho; Sharma et al.).

The purpose for the present study was to determine the frequency of ponticulus posticus in lateral cephalometric radiography of Peruvians, identify any possible genre difference and age group associations and compare our findings with similar studies in the scientific literature.

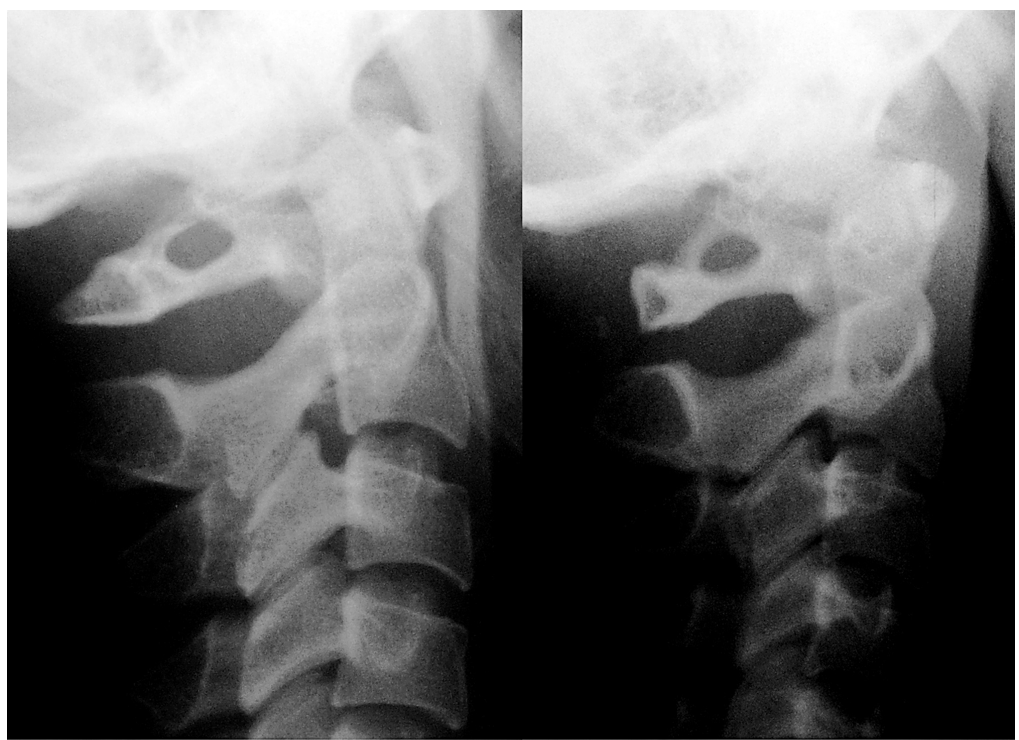

\section{MATERIAL AND METHOD}

The present study consisted in reviewing 1290 lateral cephalometric radiography from patients who attended our radiological center in Lima - Peru, between January 2010 and March 2011, in search of complete or partial PP. To obtain data from a normal population, 234 lateral cephalometric radiography of patients with cleft palate, craniofacial syndromes, poor quality image, mastoid projection over the posterior arch of atlas and missing data were excluded. After the exclusion parameters criteria, 1056 cephalometric radiographs with clearly visible skull base were able for the study purposes.

The lateral cephalometric radiography were carefully examined by a maxillofacial radiologist (IEPL) for the presence of PP in the posterior half of the Atlas, the findings were classified as follow: - Complete PP, when a complete bony bridge between the superior articular process and the posterior arch of the atlas was observed (Fig. 1).

Fig. 1. Examples of complete Ponticulus posticus. Notice the bony bridge between the articular process and the posterior arch of Atlas, and the broad insertion on the superior border of the posterior arch. 


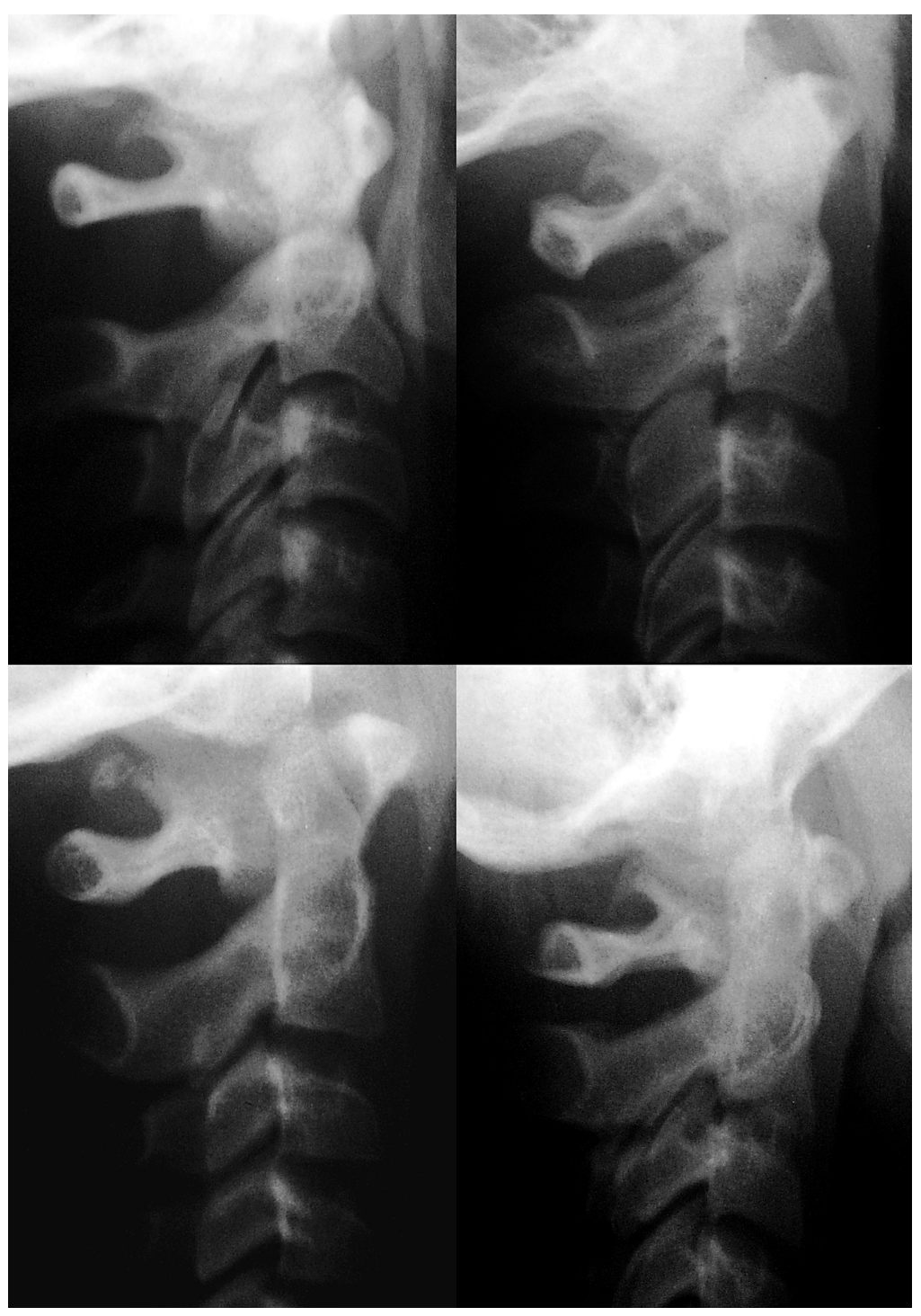

Fig. 2. Examples of partial Ponticulus posticus. Notice the incomplete bony ring from the articular process with the tip hanging inferiorly.

- Partial PP, when the ossified portion is more than a half the hemisphere or the posterior tip was hanging inferiorly (Miki et al.), exhibiting twothirds or more of a foramen created by the bony bridge (Crowe) (Fig. 2).

- No finding, including the pseudo-ponticulus, when the lateral mass of atlas overhangs to such a degree (Miki et al.).

Because we inspected neutral lateral radiography only, we were not able to determine if the anomaly was uni or bilateral. The sex and age distribution and statistical differences between genres were determined.

Database was grouped in MS Office Excel 97 and statistical analyses were performed on IBM SPSS Statistics 15. The statistical comparisons included Cramer's V and ETA association indexes to evaluate the association degree between complete or partially PP with gender and age groups (under 18 and over 18) variables. The significance level was set at $\mathrm{p}<0.05$.

To assess intraexaminer agreement in the identification of PP, 100 lateral cephalometric radiographs were reexamined by the maxillofacial radiologist two weeks after the initial analysis; Kappa coefficient value was 0.809 which correspond to a substantial strength of agreement (Sim \& Wrigth, 2005).

\section{RESULTS}

The population for the present study consisted of 1056 lateral cephalometric radiography, 559 females $(56.7 \%)$ and 457 males (43.27\%); between $3-56$ years old, the mean age was $14.05 \pm 7.43$ years; the female group mean age was $14.35 \pm 7.74$ years, and the male group mean age was $13.67 \pm 7.00$ years.

The PP frequency was $19.79 \%(\mathrm{n}=209)$, the partial PP frequency was $11.08 \%(n=117)$ and the complete PP frequency was $8.71 \%$ $(n=92)$. The sex distribution of the PP was 9.56\% $(\mathrm{n}=101)$ in females, partial PP was $5.87 \%(\mathrm{n}=62)$ and complete PP was $3.69 \%$ $(\mathrm{n}=39)$; and $10.22 \%(\mathrm{n}=108)$ in males, partial $\mathrm{PP}$ was $5.20 \%(\mathrm{n}=55)$ and complete PP was $5.01 \%(n=53)$; those differences were not statistically significant according to Cramer's V index ( $>0.05)$ (Table I).

The youngest patients with partial PP were from the six-year-old male and female group; the youngest patients with complete PP were from the nine-year-old female group and the eight-year-old male group. The age distribution according to the 18 year-old baseline was: subadult population $85.13 \%$ $(\mathrm{n}=899)$ and adult population $14.86 \%$ $(n=157)$. The PP frequency in the subadult population was $18.91 \%$; the partial type frequency was $11.34 \%$ and the complete type was $7.56 \%$. The PP frequency in the adult population was $24.84 \%$; the partial type frequency was $9.55 \%$ and the complete type frequency was $15.2 \%$; those differences were not statistically significant according to ETA's index ( $>>0.05)$ (Table II). 
Table I. Frequency distribution of ponticulus posticus (both types) related to sex.

\begin{tabular}{llcccc}
\hline & & \multicolumn{3}{c}{ Ponticulus posticus } & \multirow{2}{*}{ Total } \\
\cline { 3 - 5 } & & Complete (\%) & Partial (\%) & Negative (\%) & \\
\hline \multirow{2}{*}{ Sex } & Female & $39(3.69)$ & $62(5.87)$ & 498 & 599 \\
& Male & $53(5.02)$ & $55(5.21)$ & 349 & 457 \\
\hline \multirow{2}{*}{ Total } & & $92(8.71)$ & $11711.08 \%)$ & 847 & 1056 \\
\hline
\end{tabular}

Cramer's V index $=0.1(\mathrm{p}>0.05)$

Table II. Frequency distribution of ponticulus posticus (both types) related to adult/subadult age groups.

\begin{tabular}{llcccc}
\hline & & \multicolumn{3}{c}{ Ponticulus posticus } & Total \\
\cline { 3 - 5 } & & Complete (\%) & Partial (\%) & n & \\
\hline \multirow{3}{*}{ Age groups } & 5 to $18 \mathrm{y}$ & $68(6.43)$ & $102(9.66)$ & 729 & 899 \\
& Mean & 12.9 & 11.1 & 11.4 & \\
\cline { 2 - 5 } & $\geq 19 \mathrm{y}$ & $24(2.27)$ & $15(1.42)$ & 118 & 157 \\
& Mean & 30.3 & 28.8 & 28.7 & \\
\hline Total & & $92(8.71)$ & $117(11.08)$ & & 1056 \\
\hline
\end{tabular}

Eta's index $=0.17(p>0.05)$

\section{DISCUSSION}

The vertebrae of the cervical and the proximal thoracic part of the human vertebral column are the area undergoing the most intense transformation during phylogeny, leading to many anatomical variants (Wysocki et al., 2003). The most commonly seen variation is the PP (Wysocki et al.; Crowe), which is considered an incidental finding with an unknown anatomical importance and not a diagnosis issue (Wight et al.; Young et al.; Schilling et al.).

The mechanism of formation is not clearly understood and a subject of much debate (Manjunath, 2001; Tubbs et al.), but a number of theories have been proposed including: a genetic trait (Tubbs et al.; Paraskevas et al.; Manjunath); an occipital vertebra (Tubbs et al.; Paraskevas et al.); the result of external mechanical factors (Tubbs $e t$ $a l$.); an ossification related with increasing age (Tubbs $e t$ $a l$.; Unur et al.); and the activation of a special osteogenic potency existent in the craniocervical junction region in the connective tissue surrounding the VA possibly induced by the pulsation of the vertebral artery (Paraskevas et al.; Manjunath). So far, the ligamentous ossification tends to be a senile process that does not normally occur in young people (Sylvia et al.; Wight et al.) and, also, the prevalence of the PP does not appear to vary with age and not seems to have a predilection for older age groups (Wight et al.; Young et al.), thus, it seems to be a congenital osseous anomaly of the atlas with varying degrees of ossification and not related to age (Sharma et al.); the results of the present study found no statistically significant association between the frequency of PP (both) and adult/subadults groups, and therefore, we can confirm that the PP is a radiological finding not related to age.

The PP is formed by the bony spurs arising from the posterior surface of the lateral mass to the posterior arch of the atlas (Manjunath), and histologically is composed by a cortex and cancellous bone matrix with easily distinguishable circular lamellar patterns, all signs of endochondral ossification; those findings suggests that the PP derives from the embryonic tissue of the dorsal arch of the pro-atlas, and moreover, cartilaginous posterior bridges have been seen in fetuses and children (Sharma et al.; Paraskevas et al.; Crowe).

The PP has been related to: arm, neck and shoulder pain (Schilling et al.), buzzing in the ears (Wysocki et al.), acute hearing loss (Koutsouraki et al.), dizziness (Schilling et al.; Wysocki et al.), migraine development and various types of headaches (Sharma et al.; Schilling et al.; Kim et al., 2007; Koutsouraki et al.), paresis or paralysis of the extremities (Wysocki et al.), posterior cranial fossa circulation strokes (Young et al.; Kim et al.) and vertebrobasilar insufficiency syndromes (Koutsouraki et 
al.). Some authors suggest that clinicians should be alerted to a possible PP with patients complaining of vertigo, headache, shoulder-arm, and neck pain (Krishnamurthy et al.). Wight et al., found a statistically significant association between migraine without aura (symptom type) and PP, considering this to be an associated if not a causal factor.

The PP has been studied extensively in observational or radiographic studies in different populations (Cho; Unur et al.). In observational studies, there is more detail in the PP description when compared with radiographic studies, also the radiographic frequency of the PP seems to be lower than that of observational studies, however, variations in different populations and races should also be considered (Unur et al.).

The PP frequency found in the present study was $8.71 \%$ (complete type) and $11.08 \%$ (partial type) with not statistically significant association $(\mathrm{p}>0.05)$ with genre. Our results are similar with those reported by Schilling et $a l$, in Chilean patients, complete type $9.2 \%$ and partial type $10.1 \%$; Crowe, both types $18.9 \%$; Young et al., both types $15.5 \%$ and Kim et al., in Koreans $14 \%$ both types. Our results are similar in the accumulated relative frequency but not in the relative frequency with those reported by Leonardi et al. (2009) in his control group (complete type $4.3 \%$ and partial type $15.7 \%$ ); our results are lesser than those reported by Farman et al. (1979), complete type $8.1 \%$ and partial type $18.6 \%$ and Wight et al., both types $28 \%$; and our results are higher to those reported by Miki et al. in Japanese patients, complete type $4.9 \%$, partial type $2.93 \%$ and calcification type $1.27 \% ; 9.1 \%$ all types; Unur et al., in Turkish patients, complete type 5.1\%; Senoglu et al., in Turkish patients, complete type 5.2\% and partial type 5.8\%; Cho in Korean patients, complete type $2.61 \%$ and partial type $4.34 \%$; and Sharma et al. in Indian patients, complete type $4.3 \%$.

The sex distribution of the PP (both types) frequency found in the present study was $9.56 \%$ in females and $10.22 \%$ in males; similar results concerning higher male frequency of PP were reported by Crowe; Miki et al., found statistically significant differences between sexes Unur et al., Sharma et al. and Farman et al. found higher frequency on partial PP in males and higher frequency on complete $\mathrm{PP}$ in females. The higher female frequency of PP was reported by Schilling et al. and Kim et al.

Radiographic examination of the cervical spine may reveal a pathological disorder in asymptomatic and symptomatic subjects (Sharma et al.). The lateral cervical spine radiography is a simple technique (Krishnamurthy et al.) and the lateral cephalometric radiography is the most common diagnostic radiography used in orthodontics albeit the cervical spine area is generally omitted in cephalometric tracings (Sharma et al.), and both of them are useful to indicate the presence of a PP (Sharma et al.; Krishnamurthy et al.); but the detection of the osseous bridges on plain film radiography depends on the thickness of the bridge (Senoglu et al.), a fine thread of ossification may be difficult to detect (Kim et al.) and, bear in mind, thinner bridges are detected using 3D CT scanning only (Senoglu et al.). Therefore, the true prevalence of the PP might only be determined using 3D CT scan because of its high diagnostic value (Cho) but it would expose patients to an unacceptably high level of radiation (Paraskevas et al.).

The wide variation in shape and size of the PP is not always discernible in plain film radiography and a CT scan is needed for that purpose (Sharma et al.). Kim et al. and Cho compared CT 3D scans against plain film radiography and found statistically significant differences in the frequencies of the two types of radiographic studies influenced by the different diagnostic values of CT scans contrasted with the plain film radiography.

The pathological calcification can be categorized in two groups: heterotopic ossification (bone formation) and ectopic calcification (soft tissue mineralization). There are no reports on whether the PP represents a heterotopic ossification or an ectopic calcification (Vanden Bossche \& Vandersraeten, 2005). Tubbs et al., noted that the ossification of ligaments resulting in the formation of a PP is unlikely because ossification centers have not been observed in these structures. Crowe found PP in patients younger than 15 years old and those findings suggest that the PP is not a calcified ligament and not related to ligamental stress, because ligamentous calcification occurs years following the final formation of bone, and then following prolonged stress. Hong et al. (2008) found statistically significant differences between the partial and complete PP, and suggesting that the formation of a PP would appear to be similar to osteophyte formation, a condition also related to age. The population for the present study was predominantly under 18 years because of being an orthodontic population $(899 / 157)$ and the differences found for the age variable are in agreement with the findings reported by Tubbs et al., Crowe and Hong et al.

The surgical stabilization of the Atlas-Axis vertebrae is typically accomplished through reduction and fusion of the Atlantoaxial complex via a posterior cervical approach (Tubbs et al.) with the use of lateral mass screws for the fixation of the Atlas (Cho). The presence of a PP can predispose the VA injury during the placement of lateral mass screws (Kim et al.; Hong et al.) by mistaking the 
PP for a broad posterior lamina and then placing the lateral mass screw too superiorly and causing injury to the VA (Cho; Senoglu et al.; Young et al.; Schilling et al.; Kim et al.; Hong et al.) with unpredictable neurological deficits (depending on contralateral VA flow), or even stroke and death by thrombosis, embolism, or arterial dissection (Cho; Senoglu et al.; Young et al.). Because of that risk, the knowledge of both normal and anomalous anatomy may reduce the rate of arterial injury (Senoglu et al.); and when a PP is observed or suspected on a lateral radiography of a patient who requires lateral mass screw placement in the Atlas, the use of a 3D CT scan to find, check the size and shape of the PP of each side would be helpful for preoperative planning (Cho).

PÉREZ, I. E.; CHÁVEZ, A. K. \& PONCE, D. Frecuencia de ponticulus posticus en radiografías cefalométricas laterales de peruanos. Int. J. Morphol., 32(1):54-60, 2014.

RESUMEN: El ponticulus posticus es una osificación anómala de origen desconocido en forma de arco que va desde el proceso articular hacia el arco posterior del atlas; puede ser completo o parcial y aloja elementos vasculares y nerviosos; su diagnóstico se realiza mediante la radiografía lateral cervical, radiografía cefalométrica o tomografía computarizada. El propósito del estudio fue determinar la frecuencia del ponticulus posticus parcial y completo en radiografías cefalométricas de pacientes peruanos y determinar las diferencias de acuerdo al sexo y edad. Se revisaron 1056 radiografías cefalométricas de pacientes entre los 3 a 56 años de edad en busca de ponticulus posticus parcial o completo. La edad promedio fue de 14,05 $\pm 7,43$ años. La frecuencia de ponticulus posticus en general fue $19,79 \%$, con el tipo parcial en un $11,08 \%$ y de tipo completo en un $8,71 \%$. Se observó una mayor frecuencia en los hombres (10,22\%) que en mujeres $(9,56 \%)$. No se encontraron diferencias significativas entre la presencia de ponticulus posticus parcial o completo con respecto al sexo y a la edad ( $>0,05)$. El ponticulus posticus no es un hallazgo infrecuente, nuestros resultados fueron similares a los reportados para pacientes americanos y similares a distintos para otros grupos étnicos, se confirmo mediante estadística que el ponticulus posticus no se encuentra asociado a la edad y se discute la importancia de la presencia del ponticulus posticus en el pronóstico de la estabilización del complejo vertebral atlas-axis.

PALABRAS CLAVE: Vértebras cervicales; Radiografía; Osificación heterotópica; Radiografía; Atlas cervical/normalidades; Atlas cervical/radiografía; Articulación atlanto-axial/radiografía.

\section{REFERENCES}

Crowe, S. H. The ponticulus posticus of the atlas vertebra and its significance. Upper Cerv. Monogr., 4(1):1-5, 1986.

Cho, Y. J. Radiological analysis of ponticulus posticus in Koreans. Yonsei Med. J., 50(1):45-9, 2009.

Koutsouraki, E.; Avdelidi, E.; Michmizos, D.; Kapsali, S. E.; Costa, V. \& Baloyannis, S. Kimmerle's anomaly as a possible causative factor of chronic tension-type headaches and neurosensory hearing loss: case report and literature review. Int. J. Neurosci., 120(3):236-9, 2010.

Farman, A. G.; Nortjé, C. J. \& Joubert, J. J. Radiographic profile of the first cervical vertebra. J. Anat., 128(Pt. 3):595-600, 1979.

Hasan, M.; Shukla, S.; Siddiqui, M. S. \& Singh, D. Posterolateral tunnels and ponticuli in human atlas vertebrae. J. Anat., 199(Pt. 3):339-43, 2001.

Hong, J. T.; Lee, S. W.; Son, B. C.; Sung, J. H.; Yang, S. H.; Kim, I. S. \& Park, C. K. Analysis of anatomical variations of bone and vascular structures around the posterior atlantal arch using three-dimensional computed tomography angiography. J. Neurosurg. Spine, 8(3):230-6, 2008.
Kim, K. H.; Park, K. W.; Manh, T. H.; Yeom, J. S.; Chang, B. S. \& Lee, C. K. Prevalence and Morphologic Features of Ponticulus Posticus in Koreans: Analysis of 312 Radiographs and 225 Three-dimensional CT Scans. Asian Spine J., l(1):27-31, 2007.

Krishnamurthy, A.; Nayak, S. R.; Khan, S.; Prabhu, L. V.; Ramanathan, L. A.; Ganesh Kumar, C. \& Prasad Sinha, A. Arcuate foramen of atlas: incidence, phylogenetic and clinical significance. Rom. J. Morphol. Embryol., 48(3):263-6, 2007.

Leonardi, R.; Barbato, E.; Vichi, M. \& Caltabiano, M. Skeletal anomalies and normal variants in patients with palatally displaced canines. Angle Orthod., 79(4):727-32, 2009.

Manjunath, K. Y. Posterior bridging of the atlas vertebra in south Indians. Indian J. Med. Sci., 55(9):488-90, 2001.

Miki, T.; Oka, M.; Urushidani, H.; Hirofuji, E.; Tanaka, S. \& Iwamoto, S. Ponticulus Posticus: Its Clinical Significance. Acta Medica Kinki Univ., 4(2):427-30, 1979.

Paraskevas, G.; Papaziogas, B.; Tsonidis, C. \& Kapetanos, G. Gross morphology of the bridges over the vertebral artery groove on the atlas. Surg. Radiol. Anat., 27(2):129-36, 2005. 
Prescher, A.; Brors, D. \& Adam, G. Anatomic and radiologic appearance of several variants of the craniocervical junction. Skull Base Surg., 6(2):83-94, 1996.

Senoglu, M.; Gümüsalan, Y.; Yüksel, K. Z.; Uzel, M.; Celik, M. \& Ozbag, D. The effect of posterior bridging of C-1 on craniovertebral junction surgery. J. Neurosurg. Spine, 5(1):502, 2006.

Sharma, V.; Chaudhary, D. \& Mitra, R. Prevalence of ponticulus posticus in Indian orthodontic patients. Dentomaxillofac. Radiol., 39(5):277-83, 2010.

Schilling, J.; Schilling, A. \& Galdames, I. S. Ponticulus posticus on the posterior arch of atlas, prevalence analysis in asymptomatic patients. Int. J. Morphol., 28(1):317-22, 2010.

Sim, J. \& Wright, C. C. The kappa statistic in reliability studies: use, interpretation, and sample size requirements. Phys. Ther, 85(3):257-68, 2005

Sylvia, S.; Kulkarni, S. \& Hatti, A. Bilateral retro articular ring in atlas vertebra - a case report. Anatomica Karnataka, 5(1):81$6,2011$.

Tubbs, R. S.; Johnson, P. C.; Shoja, M. M.; Loukas, M. \& Oakes, W. J. Foramen arcuale: anatomical study and review of the literature. J. Neurosurg. Spine., 6(1):31-4, 2007.

Unur, E.; Erdog`an, N.; Ülger, H.; Ekinci, N. \& Ömer, Ö. Radiographic incidence of complete arcuate foramen in Turkish population. Erciyes Med. J., 26(2):50-4, 2004.

Vanden Bossche, L. \& Vanderstraeten, G. Heterotopic ossification: a review. J. Rehabil. Med., 37(3):129-36, 2005.

Wight, S.; Osborne, N. \& Breen, A. C. Incidence of ponticulus posterior of the atlas in migraine and cervicogenic headache. J. Manipulative Physiol. Ther., 22(1):15-20, 1999.

Wysocki, J.; Bubrowski, M.; Reymond, J. \& Kwiatkowski, J. Anatomical variants of the cervical vertebrae and the first thoracic vertebra in man. Folia Morphol. (Warsz), 62(4):35763, 2003.

Young, J. P.; Young, P. H.; Ackermann, M. J.; Anderson, P. A. \& Riew, K. D. The ponticulus posticus: implications for screw insertion into the first cervical lateral mass. J. Bone Joint Surg. Am., 87(11):2495-8, 2005.

\author{
Correspondence to: \\ Dr. Iván Pérez \\ Centro para la investigación de las disarmonías dentofaciales \\ (CIDDENT) \\ Lima \\ PERÚ
}

Email: iepl76@yahoo.com

Received: 03-05-2012

Accepted: 19-11-2013 